\title{
THE USE OF PODCASTS IN IMPROVING STUDENTS’ SPEAKING SKILL
}

\author{
Iskandar Abdul Samad ${ }^{1}$, Ahmad Bustari², Diana Ahmad ${ }^{3}$ \\ ${ }^{123}$ Syiah Kuala University \\ 1iskandar.abdul.samad@unsyiah.ac.id \\ ²bustariamd@gmail.com \\ 3diana.achmad@unsyiah.ac.id
}

\begin{abstract}
Podcast is a digital recording which contains a recorded programs from television, radio, and interviews. Many researchers have discussed about the podcast as an alternative teaching media to support students developing their speaking skills. This research article aims at finding out if there is a significant improvement on students' speaking skills by using this Podcast. Class XI IS3 was chosen as the sample of this study with total 30 students. This pre-experimental study employs pre-test and post-test. These tests are provided in the form of oral tests. The data from these tests were then calculated by using statistical formulas. The result showed that the post-test score was higher than the pre-test. The finding showed that there was a significant improvement of the students' speaking skills performance after undertaking treatments. Thus, podcast media can be used as one of the alternative media in teaching English especially speaking skill in EFL classes.
\end{abstract}

Keywords: Podcast Media, Speaking Skill, Teaching Speaking

\section{INTRODUCTION}

Speaking is widely known as an ability to share thoughts, ideas, and intentions to the other people by using a language in oral form. According to Shiamaa (2006, p. 30), speaking represents an interactive process which involves of producing and processing or receiving information to serve both interactional and transactional. In addition, Nunan (2003, p. 48) mentions that speaking is a productive skill which consists of systematic verbal utterances that carry out a meaning. This means that speaking plays an important role in communication.

In most of non-native countries, for example, China, Vietnam, and Indonesia, most students may find speaking English in a good level of functional is difficult. This is an evidence when we observed and interviewed teachers at Senior High School 11 of Banda
Aceh, Indonesia. Teachers at this school argue that the students face some difficulties in expressing ideas, choosing correct structures, lack of producing appropriate vocabulary and producing correct pronunciation. These problems occured because the students have less exposure to speaking activity.

What possibly could help students to perform appropriately in speaking is by introducing an alternative media, the podcast. According to Jordan (2007), the term podcast is a combination between the words pod (i.e., from the brand name iPod) and broadcast. The podcast is an audio/video file that is uploaded to the website where the website users can download it through the internet freely. This can be listened on any devices that support MP3/MP4 files such as on a computer, smartphone, and MP3 Player. The podcast gives chances for teachers to support students 
in developing speaking skill. The idea of using podcast media is based on some following statements from many experts in literature. Podcast is believed not just accelerating listening skill but also it stimulates the other language area for instances pronunciation, grammar, vocabulary, and learning activities (Chan et al. 2011; Kaplan-Leiserson, 2005). Other researchers, Fitria, Vianty, and Petrus (2015, p. 64-65) explain that podcast gives good contribution in case of improving students' speaking achievement. The podcast can be one of the alternatives and innovative tools that may improve the students' understanding and their accomplishment in speaking. Moreover, this idea has been discussed by Dan Schmit, an instructional technology expert in the College of Education at the University of Nebraska, which is reflected in his statement as follows:

Educators are as starting points to see how podcasting can help students' vocabulary, writing, editing, public speaking, and presentation skills. Students can also learn skills that will be valuable in the working world, such as communication, time management and problem-solving. (Schmit, as cited in Borja, 2005, p. 8).

In addition, by using the podcast, teachers have a new method of teaching to stay connect with their students outside of the classroom and to enhance learning beyond of the school schedule (Bongey, Cizadlo, \& Kalnback, 2006, p. 350-367). These researchers believe that Podcast supports students in developing speaking skill. Students can also play it on their devices anywhere and at any time as they pleased.

As described above, for the sake of making effective speaking skills, the students are required to produce good fluency and appropriate pronunciation in speaking. It would be the basis of using podcast media. Therefore, the question of this research is: "Is there any significant improvement on students' speaking skill by using podcast media?"

The researchers expect this study would contribute to filling the gap in the body of literature and also teachers especially for those who teach English at senior high school. It also could contribute to all students to improve their speaking ability, particularly in fluency and pronunciation.

\section{Podcast as Language Learning Material}

In this global era, being able to speak English is essential for people to communicate with global community (Samad and Fitriani, 2016). To help non native speakers to learn to speak this language, there are many kinds of technologies invented. According to Marshall (2002, p. 18), new opportunities can be gained by using technology. It offers users to connect with people around the world and gives a lot of unique perspectives and experiences.

There are a ton technologies invented, and one of those which provides material for language learning is called the podcast. The podcast, an uploading audio or video file to the internet, has emerged as sources in the academic field, and it provides many kinds of material in learning. The podcast is a recorded 
audio/video file uploaded to a website, so the website users can download freely and listen to it later time. Kavaliauskienè (2008) states that podcasts have given the language teacher numerous materials for teaching. Besides, Rosell-Aguilar and Fernando (2015, p. 38) claim, a podcast is similar to a public library that delivers any materials or resources needed straight to users devices. Users can download it freely without any registration and no fees required. They can choose a kind of discussion topics that was provided when they want to know something. Obviously, Rosell-Aguilar and Fernando (2015, p. 32) wrote "The podcast was a convenient and easy to use format." As was previously stated, podcast is surely easy to access, it would be attractive, and it motivates the students in learning.

In supporting this research, the idea of using podcast media is based on some following statements from the experts, in order to see the improvement of students' speaking skill. According to SZE (2006, p. 115), a number researchers have revealed the positive fruitions that podcasting can assist language education. According to (Chan et al. 2011; Kaplan-Leiserson, 2005), since the podcast is as one of the alternatives, the teacher can fairly easy to provide an authentic material in teaching.

Podcast media affirmatively shows good point for students in case of it would bring the students closer to the target language, and it affects students' attitude and motivation. In other studies, as pointed out by Mohammadzadeh (2010, p. 1193) that podcast materials can boost students' motivation and help them become more independent and confidence in speaking. By using podcast media, the teacher can support the students in building self-confidence and the learning situation enjoyable. This self-confidence may be raising due to their ability to understand the rhetoric of a particular topic as a result of listening repetion dan oral performance (Samad, 2016). This understanding makes them find the learning process is enjoyable. This study assumes that the podcast media gives contribution for the students in improving their speaking performance.

\section{Speaking Skill}

Speaking is a productive skill that is similar to writing. It has its own genre as it has several stages to reach the goal using a language in an interactive way (Martin, 2009; Martin \& Rose, 2012). Speaking involves sound to express meanings to make interaction occur. This means that speaking is an interactive process of communication that connects ideas between speaker and interlocutor with a certain purpose. Referring to Chaney and Burk (1998, p. 20), speaking is the process of sharing and constructing the sense of using oral/verbal in variety contexts. Speaking, an act of making vocal sounds, helps to assure the listener in following messages, convincing manner and thoughtful.

Harmer (2002, p. 78) mentions speaking is about generating words in the correct sequence. Speaking needs not only vocal sound involved but also needs to be aware of the aspects of speaking within which includes the 
generic structure of the speaking event that need to be followed sequentially or it is called genre (Samad and Adnan, 2017).

\section{Aspects of Speaking}

During speaking process occurred in interaction, there are several features of speaking involved. According to Duong (2014, p. 86), commonly thought of the most important aspects of speaking is grammar, fluency, accuracy, vocabulary and pronunciation.

Firstly is vocabulary. Vocabulary is a word which has its meaning in every function. A word expresses the content of ideas to avoid confusion in communication. It plays a useful role to define any objects, actions, ideas as well. According to Horby (1989, p. 289), an acceptable language is made up of the number of vocabularies. Mastering vocabulary would define someone's capability in understanding language.

Secondly is Grammar. This is similar to rigid rules in oral and written form. Brown (2000, p. 36) mentions that, Grammar is a system of rules governing the conventional arrangement and relationship of words in the sentence. Moreover, Al-Mekhlafi and Nagaratnam (2011, p. 71) write that grammar is a set of rules that determines the structure of a language, and it could be the way to combine units of a language. Combining necessary units of language help a speaker or a writer in expanding any ideas in their mind, and it makes a person a lot easier to build communication in expressing messages in spoken or written.
Thirdly is Pronunciation. This is the process of pronouncing a particular word in a proper manner. Where pronunciation should be acceptable is a necessary aspect in speaking as well. Referring to Nation and Newton (2009, p. 76 ), pronunciation is an individual sound which involves good articulation, and it has features of sound such as aspiration, voicing, voicesetting, intonation, and stress. Pronunciation plays a great role in speaking, and it gives a hint toward what is being said. The interlocutor will misunderstand on catching the meaning whether the speaker pronounces wrong pronunciation. Therefore, pronunciation is how to generate an acceptable and an unambiguous lexical word in language.

Fourthly is fluency. It means knowing about how he/she expresses ideas without using filling word ("um" and "ah") while talking to the other occurs. Yingjie (2014, p. 58) mentions that fluency is the capability to speak in effective speed and to speak smoothly and to produce the right word without thinking too much. In this case, excellent fluency will create better confidence in expressing ideas and it improves communication skill as well. To be classified as a fluent speaker, we might well fulfill this features as presented by Thornbury $(2005$, p. 8$)$ as follows, pauses may be long but not often, and pauses allow at the meaningful transition point.

Fifth is accuracy. According to Kusnierek (2015, p. 78), accuracy refers to an understanding word, right in structures, syntax, and better in catching the meaning of messages of language without part of mistakes, and it 
does not cause hesitation in interaction. Obviously, good accuracy creates impression toward how he/she delivers the message to the other.

In addition, Nunan (1989, p. 32) suggests that to be successful in speaking, the involvement of appropriate conversational formula, good ability to express phonological features of a language, excellent of mastery stress and an acceptable degree of fluency are required. All of those aspects should have emerged for the duration of speaking, and features of speaking need to be constructed well to avoid misunderstanding in speaking.

Brown (2004, p. 142-143) adds that students also need to understand the micro and macro skills in speaking. The micro skill is producing small chunks of language for instances, morphemes, phonemes, words, collections, and phrasal units. This skill plays at sentence level which focuses on the form of the ability in producing sentences. Meanwhile, macro skill refers to the person who speaks the language and it focuses on larger elements such as function, fluency, style, cohesion, discourse, nonverbal communication, and strategic options. Indeed, this macro skill emphasizes the speaker's communicative functions during the communication.

\section{Computer Assisted Language Learning (CALL)}

CALL known as a term used by teachers and students on using the computer as part of a language course in teaching and learning process. According to the concept that has been claimed by Beatty (2013, p. 7), CALL is the process of how teacher and learner use computers as a media in language improvement. That is a kind of idea that allows teacher and student to select appropriate materials and adapt it with various teaching and learning styles.

CALL covers materials design, technologies, authentic materials, and modes of instruction issues are in teaching and learning. Obviously, the materials that are designed in teaching process must convey what specifically intended and purposed for language learning. Actually, an appropriate material that is provided would bring proper quality of learning process in the class. Warschauer (2004, p. 12) mentions that CALL brings a powerful mean for students in making their path to the world. It is appropriate to help students to improve their speaking skills.

\section{The Use of CALL in Speaking Skill}

Nowadays, teaching speaking is required to be attractive and interactive. Therefore, teachers are required to support learners to practice the language. The teacher provides students many chances to rehearse English. They need to practice as much as possible. So that providing chances in practicing English would make students feel more comfortable in communication with each other. Since oral communication is important, the teacher is required pay special intention to it.

Regarding to those reason, CALL may be able to solve any barriers in supporting the learning process, seeing that the computer is effective and easy to use. The teacher could utilize the computer as a simulation that offers 
focusing on work, listening activity and oral activity for students to talk. Hammersmith (as cited in Gündüz, 2005, p. 203) notes that using computer wisely could give high contribution in developing oral skill as well. It implies that computer is a useful stuff in learning language. Indeed, that the benefits of the computer can be reached depends on how wise she/he utilizes it. Besides, the teacher and student could find learning materials on the internet freely, or they can make it with advantages of the computer itself as well.

As aforementioned, that the availibility of podcast on the internet, becomes one of the learning materials in teaching and learning. The podcast contains modes of instruction issues in teaching and learning. The teacher could use the podcast as a media at improving students' speaking skill. Furthermore, the use of this media stimulates students' interest as well. Indeed, a talk in the podcast provides every component in speaking namely, the background setting of conversation, the body movements, cultural atmosphere clearly and communicative competence. In brief, through a ton of positive experience by means of using the podcast in learning. Then, students would be able to have more motivation in learning a language. This leads them to better performances in their intelligibility, fluency, and accuracy.

\section{METHODS}

\section{Research Method}

This research employs a preexperimental approach where one group pretest and post-test design is involved.
This research aims at finding out an actual description and to prove the hypothesis whether the use of podcast media in teaching could improve students' speaking skill, especially in fluency and pronunciation. Hence, in collectingthe data, two sets of tests, pre-test and post-test, which were given to this experimental group. The researchers conducted five meetings to gather sufficient data. Those meetings were divided into one meeting for pre-test, three meetings for treatments and one meeting for post-test.

In this design, a pre-test was given before applying the treatments and post-test followed after the treatment. For these two tests, the code $\mathrm{X} 1$ is for the pre-test, and $\mathrm{X} 2$ for the post-test, while $\mathrm{T}$ is a code for treatment. In addition, the variables of this research were speaking skill and podcast. The independent variable was the speaking skill whereas dependent variable was podcast.

The population of this research is the second-grade students of SMA Negeri 11 Banda Aceh. To select them, the researchers used a lottery technique to pick the sample of this research to avoid bias. From this technique, it is selected that 30 females students of the class XI IS 3 as the research participants.

\section{Research Instrument}

The researchers collected the data by using a set of an oral test for pre test and post test. The pre-test was given to this experimental group to measure their ability prior the podcast media treatment. Conversely, post-test was conducted to measure the students' 
achievement in speaking after applying several treatments. The researchers also used his smartphone as a tool to record their speaking performance. This helps the researchers analyze their speaking. The students' performance was marked objectively. In addition, the researchers focused on evaluating students' speaking particularly in fluency and pronunciation aspect.

Materials of the test were downloaded from http://www.startcooking.com. The topic of pre-test and post-test were about the procedure and tips since they were congruent with the syllabus that used in school at secondgrade class. Besides, the talk of the podcast was not quite long; it was just about three to five minutes.

\section{Technique Data Collection}

In conducting this research, five meetings were organised, including a pre-test, three treatments and a post-test. Below is further explanation of how data collection done.

\section{Pre-Test}

In the first meeting, the researchers explained all steps in case avoiding misunderstanding process. Firstly, the researchers requested all participants to listen to a podcast talk very carefully with the topic "Vegetable Salad". When they listened to a podcast talk, they were allowed to jot down every detail information that was delivered by the speaker. Then, after they had heard the podcast talk, five minutes were free for them to prepare an outline. Then, the researchers asked them one by one to retell the podcast talk based on the topic given. Eventually, the researchers gave marks for their performance, especially their fluency and pronunciation.

2. Treatment

In the treatment meetings, the researchers used podcast as the main media in improving the students' speaking skills. The treatment was administered for three meetings; it took $2 \times 40$ minutes for each meeting. Besides, in the treatment process, the researchers used different podcast talk in each meeting. Below is the description of the treatment activities.

\subsection{First Teaching}

Initially, in this first meeting, the researchers explained all steps and asked them to follow every hint to avoid any possible of misunderstanding of it. Then, the researchers gave them first treatment.

Firstly, the researchers taught them about the procedure text and provided them an example that was taken from the podcast talk with the title "Chocolate Fudge Brownies". Next, the researchers distributed script of the podcast talk and played podcast talk for three times, and students read a script and listened to it at the same time. After that, the researchers discussed the podcast talk and gave them feedback. Then, the researchers provided them chances to ask questions about the talk and helped them while they have any difficulties. Afterward, the researchers called students randomly to retell the podcast talk which was based on the topic given in front of the class to ensure that they are familiar to rehearse and to produce appropriate fluency, 
and pronunciation. Furthermore, the researchers asked each student to reconstruct any podcast that is related to procedure text at their home. In other words, it became as their homework in every week due to treatment sessions.

\subsection{Second Teaching}

Before the researchers explained them about materials that have been prepared, the researchers selected seven students randomly to perform their homework in front of the class. The researchers also gave feedbacks for their homework by giving them advice on how to produce appropriate speaking and it is followed by stimulating them on how to build appropriate fluency and pronunciation. After that, the researchers asked the students to sit in a group which consists of four persons. Then, the researchers distributed scripts of the podcast talk for each group with a new topic with the title "Beef Stew".

The researchers played the podcast talk four times and asked every group to read the script and listen to the topic of the podcast talk carefully. Next, the researchers asked them to discuss the topic given with each member of the group. Also, the researchers provided them feedbacks and tried to convince them to imitate the way how the native speaker speaks. Afterward, the researchers invited one representative from each group to retell the podcast talk that was given. The researchers also helped them if they made inaccurate pronunciation and facilitated the students about how to pronounce a word correctly.

\subsection{Third Teaching}

The researchers conducted the third treatment. It was similar to the second meeting. Firstly, the researchers invited seven students randomly to perform their homework in front of the class, and the researchers also helped them in case correcting the inaccurate pronunciation. After that, the researchers asked the students to sit in a group which consists of four persons. Then, the researchers distributed scripts of the podcast talk for each group with the title "Roasted Chicken".

Then, the researchers played the podcast talk four times and asked every group to read the script and listen to the topic of the podcast talk carefully. Next, the researchers asked them to discuss the topic given with each member of the group. Afterward, the researchers randomly invited one representative from each group to reconstruct the podcast talk given. The researchers gave feedback for the students in case of helping them to acquire appropriate speaking.

\section{Post-Test}

At the end of the meeting, the researchers gave them a post-test. The specific aim of this post-test was to identify their improvement after such treatment sessions. The talk that was given in this test was just like the researchers once given in the pre-test. The researchers asked students to listen to the podcast talk very carefully with the topic "Vegetable Salad". The researchers allowed them to jot down every detail information as an outline. After that, five minutes were free for them to prepare the material for their speaking. Then, the researchers called them 
Vol 3. No. 2, December 2017

one by one to retell the podcast talk which was based on the topic given.

\section{Technique of Data Analysis}

For data analysis, the researchers analyzed students' score based on aspects of speaking proposed by Brown (2004, p. 179) where for each component of speaking was categorized into four band scales. In addition, the researchers recorded their speaking in every test. This helps the researchers analyze their speaking performance easier.

In statistic calculation process, the researchers analyze the data as follows:

\section{Mean Score}

Firstly, the researchers found out mean score from raw data from both tests and the median score used to see the average score. The formula of mean suggested by Arikunto (2006, p. 143) as follows:

$m=\begin{gathered}\sum f x \\ N\end{gathered}$

Where:

$$
\begin{aligned}
& m \quad: \text { the mean score } \\
& \Sigma f x: \text { the sum of the individual score }
\end{aligned}
$$

$N \quad$ : the number of sample

Then, before analyzing the data using ttest below, the researcher would initially calculate mean difference $(\mathrm{Md})$, the formula can be seen as follows:

$M d=\frac{\sum d}{N}$

Where:

Md : mean of difference between pre-test and post-test
$I S S N: 2460-7142$

$\Sigma d$ : the sum of difference between pre-test and post-test

$N \quad$ : the number of sample

Hypothesis Testing

The researchers analyzed data by using statistical formula suggested by Arikunto (2010, p. 349), t- test (t) is the primary statistic used to determine whether or not both tests (pre and post-test) have a significant difference.

The stage of the formula is put in order as follows:

$$
t=\frac{M d}{\sqrt{\mathrm{N}(\mathrm{N}-1)}}
$$

Where:

$t \quad: t$ - count

$\mathrm{xd} \quad$ : deviation each subject $(\mathrm{d}-M d)$

$\Sigma \mathrm{X}^{2} \mathrm{~d}:$ the sum of the square deviation

Md : mean of difference between pre-test and post-test

$N \quad$ : the number of sample

Finally, after the calculation and finding out the final result of the t-test, then the researchers compared them to figure out if there are any differences. In this case, the researchers used the alternative hypothesis (Ha) and the null hypothesis (Ho). For the significance, the researchers used the significant value $5 \%(\alpha=0,05)$, There are two rules in comparing the $\mathrm{t}$ - score that are proposed by Bungin (2005, p. 186); 
a. If $\mathrm{t}$-score is equal or higher than critical $\mathrm{t}$ table, so the null hypothesis is rejected, and the alternative hypothesis is accepted.

b. If t- score is lower than critical t- table, so the null hypothesis is accepted, and the alternative hypothesis is rejected.

\section{FINDINGS AND DISCUSSION}

\section{Research findings}

This pre-experimental research found that there is an improvement of the students' speaking skill by using the podcast. This improvement can be seen from the results of pre-test and post-test.Table 1 below illustrates the result of the students' pre-test and post-test and the differences between them.

Table1. Data of Students' Pre-test and Post-test and the differences

\begin{tabular}{|c|c|c|c|c|}
\hline $\begin{array}{l}\mathrm{N} \\
\mathrm{O}\end{array}$ & $\begin{array}{l}\text { Student' } \\
\text { s Initial }\end{array}$ & $\begin{array}{l}\text { Student } \\
\text { s' Pre- } \\
\text { test } \\
\text { score }\end{array}$ & $\begin{array}{l}\text { Student } \\
\text { s' Post- } \\
\text { test } \\
\text { score }\end{array}$ & $\begin{array}{l}\text { Differenc } \\
\text { e }(d) \text { of } \\
\text { Pre-test } \\
\text { and Post- } \\
\text { test }\end{array}$ \\
\hline 1 & $\mathrm{AN}$ & 65 & 80 & 15 \\
\hline 2 & A & 45 & 70 & 25 \\
\hline 3 & $\mathrm{AS}$ & 75 & 90 & 15 \\
\hline 4 & $\mathrm{C}$ & 55 & 75 & 20 \\
\hline 5 & DPS & 65 & 65 & 0 \\
\hline 6 & $\mathrm{DN}$ & 60 & 70 & 10 \\
\hline 7 & $\mathrm{DM}$ & 60 & 70 & 10 \\
\hline 8 & ER & 65 & 80 & 15 \\
\hline 9 & $\mathrm{FM}$ & 60 & 70 & 10 \\
\hline 10 & IRM & 55 & 60 & 5 \\
\hline 11 & IR & 55 & 70 & 15 \\
\hline 12 & MR & 55 & 70 & 15 \\
\hline 13 & MP & 75 & 90 & 15 \\
\hline 14 & MA & 60 & 70 & 10 \\
\hline 15 & NA & 40 & 65 & 25 \\
\hline 16 & $\mathrm{NU}$ & 45 & 70 & 25 \\
\hline 17 & $\mathrm{~N}$ & 60 & 70 & 10 \\
\hline 18 & PM & 70 & 70 & 0 \\
\hline 19 & PRJ & 65 & 75 & 10 \\
\hline 20 & RA & 55 & 75 & 20 \\
\hline 21 & $\mathrm{RN}$ & 45 & 55 & 10 \\
\hline 22 & $\mathrm{RM}$ & 55 & 85 & 30 \\
\hline
\end{tabular}

\begin{tabular}{|c|c|c|c|c|}
\hline 23 & SA & 50 & 65 & 15 \\
\hline 24 & SW & 55 & 65 & 10 \\
\hline 25 & SAM & 60 & 70 & 10 \\
\hline 26 & SN & 55 & 60 & 5 \\
\hline 27 & SR & 60 & 55 & -5 \\
\hline 28 & $\mathrm{SC}$ & 55 & 70 & 15 \\
\hline 29 & SR & 75 & 75 & 0 \\
\hline 30 & YR & 55 & 60 & 5 \\
\hline \multirow{3}{*}{\multicolumn{2}{|c|}{ Total }} & $\Sigma \mathrm{x}_{1}=$ & $\Sigma \mathrm{x}_{2}=$ & \multirow{3}{*}{$\Sigma \mathrm{d}=365$} \\
\hline & & 1750 & 2115 & \\
\hline & & $\bar{x}_{1}=58.3$ & $\overline{\mathrm{x}}_{2}=70.5$ & \\
\hline
\end{tabular}

The Table1 above shows the result score of pre-test and post-test and the differences. It can be interpreted that the highest score of the pre-test was 75 and the lowest score was 40, the total score of pre-test session was 1750, and the mean score was 58.3. In the same way, the table above shows that the lowest score of posttest was 55 and the highest score was 90 , and the total score of pre-test session was 2115 , and the average score was 70.5. Hence, it can be concluded that the students' post-test scores were higher than the students' pre-test score.

\section{The Result of Speaking Aspects in the Pre- test and the Post-test}

In teaching speaking, there are several aspects required to be mastered by students such as grammar, fluency, accuracy, vocabulary and pronunciation. However, the researchers limited to focusing at improving students' fluency and pronunciation aspect. Figure1 below presents further information of speaking aspect scores. 


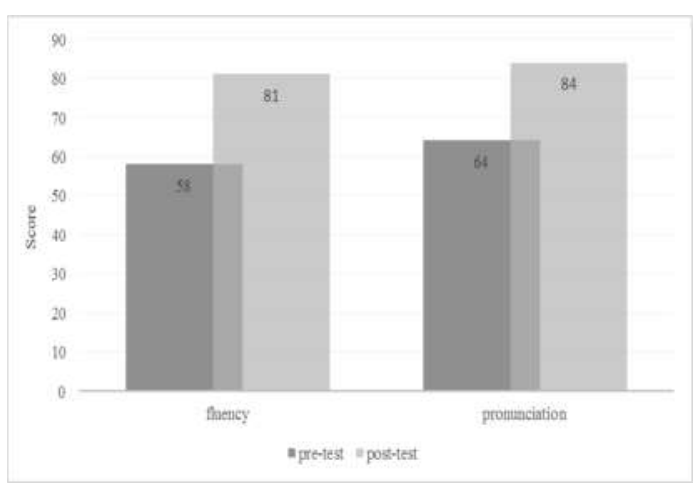

Figure 1. Speaking Aspects Improvement

The figure 1 above shows that the students had significant improvement in both aspects (fluency and pronunciation). Regarding pre-test, the total score of the students' fluency is 58 .

Then, after doing several treatments for subjects of this research, the score of this aspect has increased 23 points to 81 in the post-test. Furthermore, the score of pronunciation aspect also increases after students had the treatment as planned. In addition, the students gain better score in the post-test than the pre-test. Participants gain score 64 in the pre-test and score 84 in the post-test. In fact, they could increase 20 points from 64 to 84 . Indeed, it illustrates that the significant improvement of the pronunciation aspect reached.

\section{Hypothesis Testing}

The researchers calculated the $\mathrm{t}$ - score that was suggested by Arikunto (2010, p. 349). The level of significance had been determined before the researchers conducted this experimental research, where level significance is $5 \%(\alpha=0,05)$ set in this research. The specific aim of this level significance is to approve the hypothesis whether it is accepted or rejected. In addition, participants of this study were 30 students. The degree of freedom (df) was N-1 = 30-1 = 29, where the t-table is 2.045. Indeed, as has been noted above t- score was 8.21. So that, $\mathrm{t}-$ score was higher than $\mathrm{t}$ table $($ tscore $=8.21>$ ttable $=2.045)$.

It can be concluded that alternative hypothesis (Ha) is accepted, and null hypothesis (Ho) is rejected. In conclusion, after gathering all of the data by using several statistical formulas, it indicated that this research supported the alternative hypothesis (Ha).

\section{Discussion}

This study was aimed at finding out whether the use of podcast media in teaching can improve students' speaking skill especially in fluency and pronunciation. When the researchers have done analyzing all data, it was revealed that this research supported the alternative hypothesis. As described in the research background, that students found many difficulties in speaking performance. They could not express ideas, speak fluently, use right structures, lack of producing appropriate vocabulary and produce correct pronunciation. However, after doing several treatments, it showed the previous problems encountered by the students was solved, especially their fluency and pronunciation became better.

Previously they made mistakes, but after they had rehearsed to reconstruct podcast every week during treatment sessions, a number of students showed a satisfactory progress in certain aspects. For example, in the pre-test, several students produced incorrect pronunciation, and not fluent in speaking. 
When they had enough practice in treatment sessions, they can solve these problems calmly in the post-test. Meanwhile, some other students also made decent improvement in more than one aspect, including vocabulary, grammar, and expressing ideas.

Based on the explanation aforementioned, it is flawless that implemented podcast media can increase students' speaking skill, where the result showed statistically significant was found. This result was consistent with the finding of Fitria, Vianty, and Petrus (2015, p. 55-56) which explains that podcast helped the students in gaining better achievement in speaking. Podcast positively brings many advantages, and it completed objectives of this research. In addition, students can enhance their speaking aspects by practicing to reconstruct the podcast talk that they have heard.

Furthermore, the researchers also found that the application of podcast media in the class made the students more active in practicing speaking. For instance, the students feel a bit nervous and less confident in performance their speaking in front of the class, but after rehearsing a lot in treatment sessions, they became calm and better than the pre-test. This situation was similar to the evidence that was found by Mohammadzadeh (2010, p. 1193) that podcast materials can boost students' motivation and help them become more responsible, independent and confident. Thus, since podcast is one of the authentic material and a real language which is produced by native speaker, so the students can imitate the way how the native speaks real language. It is believed that podcast media could enhance students' in building critical thinking, comprehension, and expanding vocabulary and it is more enjoyable while the students can read a text and listen at the same time.

\section{CONCLUSION}

The researchers concluded that the podcast media demonstrated positive fruitions on students' speaking achievement. In addition, this media could cope with students' problems in speaking, such as incorrect pronunciation and not good fluency. Where these problems only procured them unexpected score to pass Minimum Completion Criteria (Kriteria Ketuntatasan Minimal) in the test conducted by the researchers. Obviously, after post-test was held, the students' score was increased; it implies that their speaking performance have improved. Given this point, applying podcast media in teaching speaking showed positive result in assisting students to improve speaking performance especially pronunciation and fluency.

Based on findings of this research, the researchers would like to propose some suggestions. For teachers, this media is appropriate to be implemented in the classroom. This helps teachers to improve students' speaking skills and to provide correct teaching materials. Nowadays, teachers do not need to worry about how to provide suitable material for teaching. There are many materials available on the internet. Thus, the podcast is recommended for a teacher in solving 
problems, for example finding out appropriate material for students. The teachers only need to download it for good. There are a ton of podcast materials stored in what is called the internet which are free to download. In short, these suggestions are not only directly addressed for the English teachers of SMA Negeri 11 Banda Aceh, but it also fits with other English teachers who teach speaking.

In order to improve individual skill such as speaking skill, the students should immerse themselves in learning English. It means that they have to enlighten themselves with English. Students need positively to boost time in practicing English because learning English at school is not enough. Thus, one of many ways that they can do in practicing English is downloading a podcast. Additionally, podcast exposures components in speaking namely, background setting of conversation, body movements, cultural atmosphere clearly and communicative competence. Obviously, through a ton of positive experience by means of using the podcast in learning, students will earn more motivation in learning a language, and it leads them to the better performances in their intelligibility, fluency and pronunciation.

\section{REFERENCES}

Al-Mekhlafi, A. M., \& Nagaratnam, R. P. (2011). Difficulties in Teaching and Learning Grammar in an EFL Context. International Journal of Instruction, 4(2), 69-92.

Arikunto, S. (2006). Prosedur Penelitian: Suatu Pendekatan Pratik. Jakarta: Rineka Cipta.
Arikunto, S. (2010). Prosedure Penelitian: Suatu Pendekatan Pratik (Revision ed.). Jakarta: Rineka Cipta.

Beatty, K. (2013). Teaching and Researching: Computer-Assisted Language Learning $\left(2^{\text {nd }}\right.$ ed.). New York: Routledge.

Bongey, S.B., Cizadlo, G., \& Kalnback, L. (2006). Explorations in course casting: Podcasts in higher education. CampusWide Information Systems, 23(5), 350367.

Borja, R. R. (2005). Podcasting craze comes to K-12 schools. Technology in Education, (Online), Retrieved January 29, 2017 from

http://www.edweek.org/ew/articles/2005/ 12/07/14podcast.h25.html?qs=Podcastin $\mathrm{g}+$ craze + comes + to $+\mathrm{K}-12+$ schools

Brown, H. D. (2000). Teaching by Principles. An Interactive Approach to Language Pedagogy. San Francisco: Longman Inc.

Brown, H. D. (2004). Language Assessment. Principles and Classroom Practices. New York: Longman.

Bungin, B. (2005). Metodologi Penelitian Kuantitaitf: Komunikasi, Ekonomi dan Kebijakan Publik serta Ilmu-ilmu Sosoial Lainnya. Jakarta: Kencana.

Chan, W. M., Chi, S. W., \& Lin, C. Y. (2011).Students' Perceptions of and Attitudes towards Podcast-Based Learning - A Comparison of Two Language Podcast Projects. Electronic Journal of Foreign Language Teaching, 8(1), 312-335.

Chaney, A. L., \& Burk, T. L. (1998). Teaching oral communication in grades $k \square 8$. Boston: Allyn \& Bacon.

Duong, T. M. (2014). An Investigation into Effects of Role-Paly in an EFL Speaking Course. Global Journal of Foreign Language Teaching, 4(2), 81-91.

Fitria, U., Vianty, M., \& Petrus, I. (2015). Using Podcast to Improve Students' 
Listening and speaking Achievements. About Teaching. Retrieved December 13, 2016 from http://www.ejournal.unsri.ac.id/index.ph $\mathrm{p} /$ jenglish/article/download/2218/1036

Gündüz, N. (2005). Computer Assisted Language Learning, Journal of Language and Linguistic Studies, 1(2), 193-214.

Harmer, J. (2002). How to Teach English (2 ${ }^{\text {nd }}$ ed.). London: Longman Press.

Horby, S. (1989). The Practice of English Language Teaching. London: Longman Press.

Jordan, M. (2007). What a podcast is and everything you need to know about podcasting. Technology in Education. Retrieved January 13, 2017 from http://www.americanchronicle.com/articl es/viewArticle.asp?articleID=47099

Kaplan-Leiserson, E. (2005). Trend: Podcasting in academic and corporate learning. Retrieved March 15th, 2016 from http://trainingthetrainers2010.pbworks.co $\mathrm{m} / \mathrm{w} /$ search? $=$ podcasting

Kavaliauskienè, G. (2008). Podcasting: A Tool for Improving Listening Skills, Teaching English with Technology, 8(4). Retrieved November 9, 2016 from http://cejsh.icm.edu.pl/cejsh/element/bw meta1.element.desklight-aa648d8c-e9354f9f-b987-3107a34a61b3

Kusnierek, A. (2015). Developing Students' Speaking Skill through Role-Play. World Scientific News, 1(2), 73-111.

Marshall, J. M. (2002). Learning with technology: Evidence that technology can, and does, support learning. California: Cable in the Classroom.

Martin, J. R. (2009). Genre and language learning: A social semiotic perspective. Linguistics and Education, 20, 10-21.

Martin, J. R., \& Rose, D. (2012). Genres and texts: Living in the real world. Indonesian Journal of SFL, 1(1), 1-21.
Mohammadzadeh, B. (2010). Podcasts: Teacher and Student Friendly Technology in Language Teaching and Learning, New Trends in Education and Their Implications, 1193-1198.

Nation, I. S. P., \& Newton, L. (2009). Teaching $E S L / E F L$. New York: Routledge.

Nunan, D. (1989). Designing Tasks for the Communicative Classroom. New York: Cambridge University Press.

Nunan, D. (2003). Practical English Language Teaching. Boston: McGraw Hill.

Rosell-Aguilar, F. (2015). Podcasting as a language teaching and learning tool, Case Studies in Good Practice. 10(3), 31-39.

Samad, I.A. (2016). Improving Students' Competence in the Thesis Defence Examination in Two Universities in Aceh, Indonesia. Unpublished Doctoral Dissertation. University of New England: Armidale.

Samad, I.A \& Adnan, Z. (2017). Using A Genre-Based Approach to Prepare Undergraduate Students For An English Thesis Defence Examination: An Experimental Study to Address the 'Pedagogical Controversy'. Linguistik Indonesia Journal, vol 35 (1), 75-93

Samad, I.A \& Fitriani, S.S (2016). English proficiency: $A$ challenge and an opportunity in facing ASEAN Economic Community. Proceeding of Annual International Conference, Syiah Kuala University, 5-6 October. Banda Aceh: University Press.

Shiamaa, A. E. F. T. (2006). The Effectiveness of Task-Based Instruction Program in Developing the English Language Speaking Skills of Secondary Stage Students. Ain Sham: Ain Sham University. (Thesis). Retrieved March 11, 2017 from files.eric.ed.gov/fulltext/ED523922.pdf. 
Journal of English Language and Education

Vol 3. No. 2, December 2017

ISSN : $2460-7142$

SZE, P. (2006). Developing Students' Listening and Speaking Skills through ELT Podcasts [Abstract]. Educational Journal, 34(2), 115-134.

Thornbury, S. (2005). How Teach Speaking. Edinburgh: Longman.

Warschauer, M. (2004). Technological Change and the Future of CALL, New Perspectives on CALL for Second and Foreign Language Classrooms, 1-15.

Yingjie, Y. (2014). The Development of Speaking Fluency: the 4/3/2 Technique for the EFL Learners in Chine. International Journal of Research Studies in Language Learning, 3(4), 5570. 